\title{
Jawawawo Natural Monisms: Revelation Dimension of Peo and Inspiration for Faith-Dialogue in Multi Religious Society
}

\author{
Yakobus Ndona ${ }^{1}$, Paulinus Tibo ${ }^{2}$ \\ ${ }^{1}$ Pancasila Education and Citizenship Study Program, Faculty of Social Sciences, Universitas Negeri Medan, \\ Medan, Indonesia \\ ${ }^{2}$ Catholic Regious Education Program, SekolahTinggi Pastoral Santo Bonaventura KAM, Indonesia \\ yakobusndona@unimed.ac.id
}

\begin{abstract}
Traditional faiths are still often regarded as animism, dynamism and superstition. The fact shows that traditional fatihs indicate various virtues and truth that can be inspiration for development of multi religious community existence today. The writer, from the result of research toward artefact metaphysic dimension in Jawawawo customary commuity, Central Keo, Indoneia, found out the form of natural monism religiousity which derives from genuine revelationexperience. Peo manifests vision of divinity in traditional faith of Jawawawo community, namely that is transcendent as well as immanent, absolute at once covers and underlies everything, far unlimted, at once involves in history and human life.This divine image shows that traditional faith of this community cannot be categorized as animism, dynamism and superstition; on the contrary, it gives inspiration for self development and faith-dialogue in multi religious community at present.
\end{abstract}

Keywords: Peo; revelation; divine; Ngga'e Mbapo; natural monistic.

\section{Introduction}

A lot of countries, including Indonesia in the influence of monotheism majority, have put aside traditional faiths. Most of traditional faiths in the past time were grouped into Hinduism group. Public community, in the background of monotheism conception, believing in divine revelation think traditional faiths as dynamism, animism and superstition. This stigma has faded the virtues and impoverished the truths of traditional faith community, even once in a while has shown various intolerant acts.

The fact shows that traditional faiths illuminate the light of truth, awareness of mysterious powers, even acknowledgement to the highest divinr might (KWI,1993,p.310). The existence of traditional faiths, apart from various limitation, becomes an essential answer in human fundamental problems. The writer, in this background, researches revelation dimension of artefact Peo, center of Jawawawo customary community, Central Keo, Province of Nusa Tenggara Timur, Indonesia, the period of February 2017 until June 2018. This research is funded by the Ministry of Research and Technology of Higher Learning (Kementerian Ristek Dikti RI) budget year 2018 contract number 027/ un33.8/II/2018.

Many writers, like Fransiscus Owa, Philipus Tule and Gregory Forth, have discussed artefact $P e o$ in the context of Keo culture. This article focusses on the relevation dimension of $P e o$ which has underelain the traditional faith of Jawawawo community. Three basic questions become the model in this analysis: (1) what revelation aspect of Peo is there in Jawawawo customary communty? (2) what religiousity model of Jawawawo customary community is manifested in Peo; (3) what contribution does the revelation of Peo and religioustity model of Jawawawo community give to the life of multi religious community at present. 


\section{Research Method}

This research employs qualittive approach. The choice of this approach is based on the consideration that the analysis of revelation of Peo refers to the sense, which can only be understood through interpretation, and descriptive imagination. The data are obtained through observation of daily life of Jawawawo customary community, interview with custom figures, and collection of rite document in Peo rehabilitation. The obtained data are analized by reduction, hermeunetics, reflection and heuristics.

\section{Discussion}

\subsection{Peoas Milestone of Jawawawo Customary Community Discussion}

The Jawawawo community, including Keo tribe, now settle in part of south region of Central Flores around Nangamboa up to Maumbawa. This community now includes in the district of central Keo, Kabupaten Nagekeo, East Nusa Tenggara(Ngada, 2009, p. 7).

Jawawawo is not the only one who has the Peo. Nearly all customary communities in the district of Keo have Peo as a milestone of unity(Forth, 2002). The existence of Peo in Jawawawo deals with the position of Jawawawo as the main village (nua pu'u) of customary community of two other villages, they are Ua and Romba Wawakota.Peo of Jawawawo functions as the pivot of the three mentioned villages.

Jawawawo has a pair of Peo, Peo fai (Peo of mother) and Peo aki (Peo of father). Peo fai consists of embu wood(Tule, 2004, p. 110), ${ }^{\mathrm{i}}$ two symetrical braches like Y with 4,5 meter high on the ground, equipped with earrings (uli wolo) at the east and west side; white hole at the space of branch ( $p u^{\prime} u$ nda'a) looks like female sexual organ (odo mea ata fai); animal icon and celestial creatures at the north side of the branch, and earth creatures (lizard, scorpion, centipede, crocodile at the south side; the palm at the back of the branch; and two statues of murai bird (koka) at the top of the branch.

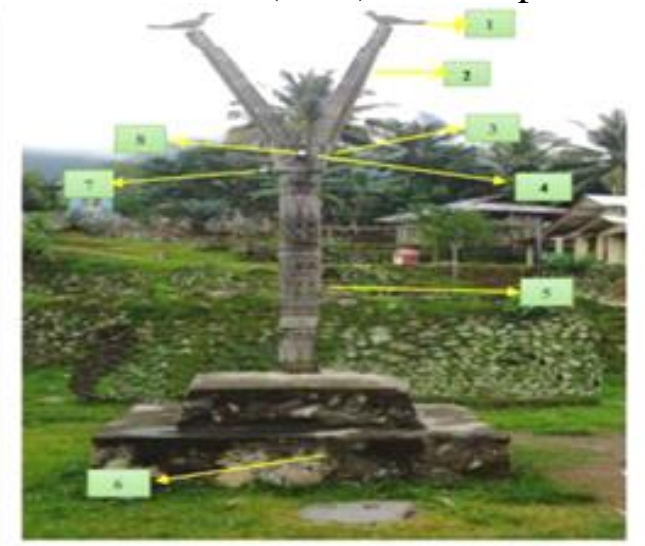

Figure 1: Peo Fai

Peo fai has eight basic elements, namely pu'u $P$ eo or Peo's base (number 6), toko Peo or Peo's pole (number 5), nda' a Peo or Peo's branch (number 2). koka or magpie (number 1), left and right side: carvings of moli or crocodile, ebe or lizard, eko teko or scorpion, mupa kua or centipedes (number 3) and ult wolo or earrings (number 7), front side: carvings of ndada or star and eagle (number 4). odo mea ata fai or female genital (number 8).

Figure taken by Yakobus Ndona, June $19^{\text {th }} 2018$

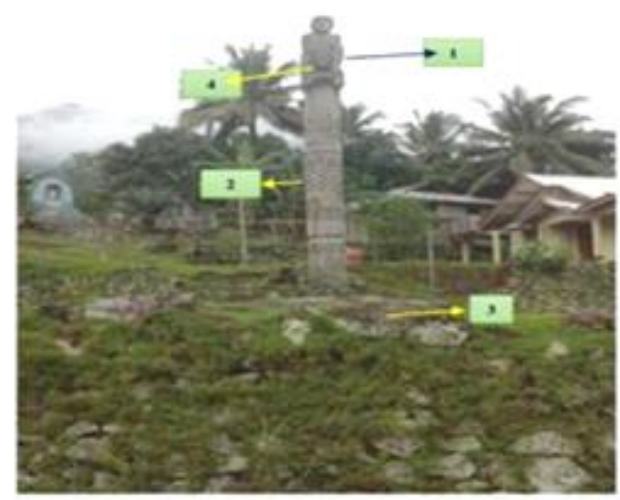

Figure 2: Peo Aki or Mandu.

Peo aki or madhu Peo aki or madhu has four basic elements, namely pu'u peo or Peo's base (number 3), toko Peo or Peo's pole (number 2), and ana jeo or the statue of a naked man (number 1), with male genital (number 4).

Figure taken by Yakobus Ndona, June $19^{\text {th }} 2018$ 
Peo aki also consists of "embu"wood, oval and pointed shape, with 3,5 meter high and at the top above naked male statue shape sitting with protruding pennis ("ana jeo"). Jawawawo community ention Peo aki with madhu(Fransiskus, 2016, p. 53).

Peo fai is precisely built in Jawwawo village, with the position of two branches to east and west so that it looks like a woman with two stretching hands facing Peo aki. Peo aki is inthe north, one yard of the house higher with position facing Peo fai, like a husband looking at his wife. The position of Peo fai and Peo aki, according to custom figure of Keo, Severinus Rangga, describes the relation of sexual intercourse of husband and wife (muri nambu fai aki) (Rangga, 2017).

\subsection{Peo as Monument of Revelation}

$P e o$ in metaphysic perspective is monument of revelation. Karl jaspers names such objects chiffer or divine symbols. $P e o$ as the monument of revelation has a metaphysicmeaning due to the relation with the Being, and becomes the chief principle of all Beings; because it is in the divine mystic current which ascends towards divine domain, and descends to represent (wirklich) and reveal divinity(Jaspers, 1959, p. 41).

$\mathrm{Peo}$ is a monument which translates genuine revelation experience of Jawawawo ancestors into physical objects. Revelation experience is exclusively mystical experience which makes Peo and any objects not able to translate the totality of revelation experience. $P e o$ as the translation monument contains aspect of conception and reduction. The mobilized and localized presence in Peo has limited space so that the divine revealed elements cannot be completely documented; nevertheless, Peo constantly has the real presence of the revealed divinity. The likelihood of natural, historical and social context enables the customary Jawawawo community to have the same construction of meaning. Peo can be said as a monument describing the divine vision of Jawawawo community.

Peo belongs to excellent art and powered revelation. Excellent art as Karl Jaspers says has an ability to lead people to original revelation experience and to visualize the divine vision in concrete form(Jaspers, 1971, p. 170). Peo includes an art which unites various elements of art and culture at the divine reality; and provides strength to variously forgotten elements to revoice(Jaspers, 1971, p. 173). ${ }^{\text {ii }}$

Peo belong to carving art which can present the divine voice in physical form and retain the presence in human awareness from one generation to anothr generation(Jaspers, 1971, p. 173). Peo within the role as the pivot of community is a node which moves various cultural elements to make the divine presence more complete. Peo involves the art of architecture, as seen in structure, design of layout and motif which functions as transparance for divine elements and stimulatesthe subject intuition to ascend to unlimited space; also music art like nggo dambaii which stimulates the subject intuition in the experience of divine greatness; dancing art like bebi ja' $i^{i v}$; which presents the divine elements in motion; and poetry art like naro, Mbea Sa, and Sua Soda presenting the divine elements in verebal expression. Peo from the meaning pattern belongs to the monument creating the divine imagination through universal image and employing various metaphors(Jaspers, 1959, pp. 61-62).

\subsection{Peo Fai the Symbol of Earth Motherhood}

Jawawawo community comprehends the milestone of Peo as ancestors who dominate and hold Jawawawo land in high esteem. Two branches of Peo fai represent the twokinds of Jawawawo land, namely the chief land (tana odo watu ebho) and the land of war result 
(tanafai watu ama). The two branches of Peo fai resting on th milestone of Peo (toko Peo) describes the two kinds of Jawawawo land rested and supported by ancestors. A question arises: why the kinds of Jawawawo land are symbolized with two branches of Peo fai? Why is the form of Peo fai like Y? What is the relationship between the form Y and the land?

The two branches of Peo which looks like a curve (V), according to resources, describes the motherhood (female groin)(Jaspers, 1971, p. 173).This understanding is supported with the white hole atthe bottom of branch which describes the womb of woman (odo mea koo ata fai) and earrings (uli wolo) at both sides. This is in line with male statue (ana jeo) at Peo aki appearing with portruding penis as a symbol of virility.

What is the meaning of feminism characteristics of Peo fai? These characteristics probably have a relation with the title given to Peo fai as ine mere (mother with big womb). What is meant by ine mere? Some people interpret ine mere as female couple of ancestor, pioneer of the village and customary community. Other people interpret it as representative of the whole female ancestor(Tule, 2017).These two interpretations are hard to accept. The title ine mere derives from the comprehension of Peo fai as ancesgor who unites and respect Jawawawo land. It cannot be subjected to female ancestor, including the pioneer of female couple ancestor. It is difficult for Jawawawo community to accept female ancestor as land authority and support. Woman in Jawawawo patriachal community never has the right of land. Land cannot be owned and inherited by male generation. The genealogical story reflect in reko (verse/episode) and naro, ${ }^{\mathrm{V}}$ also the declaration of Peo building describes only the involvement of male ancestor in clearing aay the path and leading the community.

The title mere refers to divine dimension in traditional Jawawawo belief. The question is: what is the relation between feminism characteristics of Peo fai and divinity? Do feminism characteristics describe the divine personality? This argument is difficult to accept. Jawawawo community does not know personal divine figure. Appeal prayer (suasoda) of Jawawawo has never mentioned certain divine figure. The appeal prayer is always addressed to the ancestor of paternal descent line.

The formulation of declaration of Peo building (bhea pije pu'u) can give an indication about the concept of ine mere. The declaration starts with a statement to Peo fai: su'u inembupu(respect old mother) and wangga ame uwa(hold up gray-haired father). The address of su'u ine mbupu is of course intended to Peo fai, but wangga ame uwa is odd toattach to Peoaki.The call of ame uwa implies the meaning of old man, wise and powerful(Tule, 1998, p. 86). The call of ame uwa to Peo fai indicates that Peo fai cannot be reduced as the represetative of female ancestor.

Another indication is the string of buffalo prey at the celebration of Peo building. The string is only bound to the supporting pole $(a k a)$ surrounding Peo fai, though the end of the string is bound the bottom of madhu. Position and attitude of declaration carrier is addressed to Peo fai. The dance rites of Peo building is also just surrounding Peo fai. The rite series of Peo restoration is focused on Peo fai(Gani, 2018). Why Jawawawo community which is patrimonial is precesiley focused on Peo fai and tend to neglect Peo aki.

Title ine mere does not describe Peo fai as representative of female ancestor. Ine mere is Jawawawo land. Jawawawo ancestor regards land as mother for the whole life. Sensual aspect of Peo fai wants to describe the feminism dimension of land. Land is ine mere (mother with big womb), who gives birth to the whole life.The use of female sexual organ as a symbol of Peo fai becomes the core of womanhood identity as well as the origin of life. 
The concept of land as big-wombed mother has probably rooted long in Jawawawo tradition, as seen in three traditional Jawawawo expressions: ine tama ame waatu (mother, land, father stone), tana mone ta ko'o kita, kita nglala ko'o tana(land is not ours, we belong to land), and tama tuka ine (come into the mother's womb). The title ine tana ame watu, clearly describes that land is the origin of life. Land, which gives birth to lif, becomes the owner of life (kita ngala ko'o tana), which also raises up and accepts back into its womb when the period of life has ended (tama tuka ine) (Fernandez, 1991). Some myths of central Keo community also tells about the man origin from the earth depth through spring, land and stone. ${ }^{\text {vii }}$ Jawawawo people as peasant directly encounter land phenomena which continuously reflect the mystery of life. Land keeps on producing life, providing food to raise up and make water out to look after. Land phenomena manifest the power of divine motherhood which creates and provides life.

\subsection{Peo Aki as Symbol of Celetial Father}

Jawawawo community calls Peo aki ame dewa (powerful father). This call cannot be understood either as representative of male ancestor. The concept of Peo aki as ame dewa should be related to the rite of rain request (kuda kepa) around Peo aki when facing the long drought. The rite practice of rain requestat the bottom of Peo aki indicates that Peo aki is therepresentative of celestial ruler that is called mother and father of rain (ine ko'o ura, ameko'o ura) the ruler of season and decider of nature cycle. Jawawawo communty calls the figure of celestial ruler with Ngga'e Mbapo.

This symbolism is in line with the branch form of Peo fai which looks like two hands stretching up. The position of Peo fai, at one side facing to Peo aki, identical to the position of wife facing her husband, but on the other side, the two branches of Peo fai are indentical to both hands stretching up. These two positions are directed to the same object, the celestial ruler. The position of Peo fai facing up to Peo aki is identical to the hands stretching up to Ngga'e Mbapo who reigns the heaven.

This symbolism shows that movement revelation does not stop at the ancestor who dominates and respects the land. The respect of land implies that there isa higher side as a goal of land give away. Symbolism of land respect by ancestor really continues the rite of poto udu tana(land give away). Tanafai watu dua achieved from the war victory, through the rite of poto udu tana has been given to the power of ancestor, and then respected by ancestor in order to be raised at the constant relation with Ngga'e Mbapo.

Jawawawo community believes that heaven is the residence of throne of Ngga'eMbapo. The position of anak jeo sitting at the top f Peo aki describes Ngga'e Mbapo sitting in his throne in high sky. This description is clarified in the poem of reko naro, restoration of $\mathrm{PeO}$ indicating that Ngga'e Mbapo is sitting in his throne (ngambe sare) on the roof of sa'oen'nda. The roof of sa'o en'nda in Keo cosmology illustrates the heaven or sky. The painting of Ngga'e Mbapo sitting on the roof of sa'o en'nda tells Ngga'e Mbapo sitting in his throne in heaven. Heaven, on one side, due to its unlimited height manifests the transendence, solemnity and absolutism of Ngga'e Mbapo; but on the other side, because it shines the light and pours the rain continuously, it also manifests the divinity of Ngga'e Mbapo who determines the fate of life on this earth. 


\subsection{Ngga'e Mbapo - The Highest Divinity Traditional Faith of Jawawawo}

The structure of Peo fai and Peo aki, clarified with th structure of sa'o en'nda points out to celestial power as the highest divinity. Jawawawo community calls it with Ngga'eMbapo. Ancestor is experienced as provider of life blessing, and nitu Ngga'e as mediator ofNgga'e Mbapo; however these two divine figures attach to Ngga'e Mbapo. Peo clarifies that life can go on only in constant relation with Ngga'e Mbapo.

The term Ngga'e (Ga'e found in West Keo and Nage community) is often united with the word ngale, becomes ngala Ngga'e, meaning the side which owns it. The question sai tangala ngga'e wants to ask who the owner is.(Tule, 2004, p. 199).

The term Ngga'e most probably derives from the structure of Keo feodal community which opposes between ngga'e (master) in one side, and oo'o (servant) in the other side. Ngga'e is master, the side which own both land and servant, whilst oo'o (servant) the side which is owned and serves ngga'e. The term ngga'e becomes formal addressing for landlord and the owner of servants. The term ngga'e is attached to the highest divinity to clarify the ownership of everything. Ngga'e is an absolute owner different from ownership limited landlord. The term ngga'e refers to the word meaning which parallels to Indonesian word 'Lord' from Malay word 'lord' meaning the owner or man in power similar to the Greek word,Kyrios, and Hebrew, Adonai(Heuken, 1991, pp. 88-89).

Jawawawo people often unite the word ngga'e and Mbapo so that it becomes Ngga'eMbapo; and also Mbapu so that it becomes Ngga'e Mbapu. The unity of the word Ngga'e and Mbapo, Ngga'e and Mbapu has a backgrund of tendency of Jawawawo people and most of Keo people who think binarily(Forth, 2002, pp. 290-293). The names in Keo, both those referring to man, place, position and orientation always consist of two words in harmony or in contrast(Tule, 2004, pp. 194-195).

The first word of the name indicates personal identity, and the second comes from the name of mother who gives birth. Similar characeristics are found in the name of place, like UduAe(water coconut spring), Ombo Keta (cold valley), Nio Ndoa (twin coconuts), Mabha Pisa (muddy plain). ${ }^{\text {vii }}$ The subject of the term Ngga'e Mbapo or Ngga'e Mbapu lies at the word Ngga'e. The word Mbapo or Mbapu is attached to the word Ngga'e with the purpose of clarifying Ngga'e identity. The term Ngga'e Mbapo means Ngga'e which is Mbapo, and likewise the term Ngga'e Mbapu.

The word Mbapo in Keo glossary means the whole, complete and entire(Tule, 1998, p. 43).Ngga'e Mbapo The termNgga'e which covers the whole divinity with his entire existence and strength. The term Mbapu means celebration or party(Tule, 1998, p. 43). Ngga'e Mbapu means Ngga'e which is celebrated in custom rites. The term Mbapo and Mbapu refer to the olutrly.word meaning, does not indicatedifferent divinity but confirm the identity of Ngga'e divinity. As such Ngga'e Mbapo means Ngga'e which covers the entire divine power, owns and dominates everything absolutely. The term Ngga'e Mbapu can mean Ngga'e which is believed andcelebrated in a rite. This concept underlies the use of the word Mbapu at the word Ngga'e in the rite of pala manu, and Mbapo is also used to replace Ngga'e at the poem (episode) naro restoration of Peo. The word Mbapu is more concerned with the rite aspect, and the word Mbapo emphasizes more on essence aspect.

Prayeer exclamation ( sua soda) in pala manu rite employs the word Mbapu because of celebration context;nevertheless the use of this term also reveals the understanding of Ngga'eessence. The term Mbapu in pala manu rite is placed at the opposing pole of the word Ngga'e. Prayer exclamation in pala manu rite greets Mbapu ndia tama(Mbapu on the land), 
Mbapu eko dau(Mbapu directed to the south), Mbapu wewa en'nda (Mbapu in the yard), Mbapu peka rade (Mbapu in the west) Mbapu ten 'nda dewa (Mbapu in the whole community) as the opposite pole of Ngga'e reta diru (Ngga'e in heaven), Ngga'e ude rede (Ngga'e with head to the north),Ngga'e pu'u Peo (Ngga'e at the bottom of Peo), Ngga'e wisamena(Ngga'e in the east) and Ngga'e udu rede(Ngga'e with the head above) and Ngga'esa'o mere(Ngga'e in the main house). The use of the word Mbapu as the opposite of Ngga'e means to show the dimension of Ngga'e presence in the entire area fo cosmos. Those locations are the residence of Ngga'e and Mbapu is coordinate spots of $N g g a$ 'e presence in cosmos space.

Jawawawo communty believes that, which means $\operatorname{Fga}^{\prime} \mathrm{e}$ is the beginning and the very beginning, and Mbapo has existed since very long time ago(Gani, 2018). The placement of the word geo to the word ebho becomes the culmination limit of language to reveal the eternality of Ngga'e Mbapo. The formulation of Ngga'e ta mudu, ta mudu odo, Mbapo ta ebho, ta ebho geo has a mening that the existence of Ngga'e Mbapo is unlimited or unmeasureable.

Jawawawo community also often calls Mbapo as ta do'e roe. Ta do'e has meaning as the beginning base and source. The term ta mudu odo will emphasize Ngga'e as the starting point preceding everything. The term ta do'e roe more emphasizes the position of Ngga'e Mbapo as the beginning, base and source of everything. Ngga'e Mbapo is called ta muduodo, ta ebho geo, ta do'e roe, and that means Ngga'e Mbapo is the very beginning, base and source of everything.

\subsection{Ngga'e Mbapo as History Organizer}

Refrain of the second and third reko naro Peo restoration confirms the involvement of Ngga'e Mbapo in the history of community. Refrain of the second verse indicates Ngga'ebhade modo. The term Ngga'e bhade modo refers to the word bhade meaning to turn up, and the word modo means true (Tule, 1998, p. 15). Ngga'e bhade modo can mean Ngga'e turns up or plans correctly.

Refrain in the third reko, Mbapo wenggombe'o refers to the word wenggo meaning to move, to shake, and the word mbe'o means true, good, wise and exact. Mbapo wenggombe'o means Mbapo shakes well, arranges perfectly, and acts wisely. These two phrases want to clarify that Ngga'e Mbapo has designed and arranged the history of Jawwawo correctly, wisely and perfectly.

This poem describes the faith of Jawawawo community that history is not only a series of events in time, but also a design and providence of Ngga'e Mbapo. The involvement of Ngga'e Mbapo not only relates to the past prosperity but also relates to various experience like conflict, war, though painful, but produces various virtue. Jawawawo history is history of Ngga'e Mbapo's tendency. As such Peo is the clarity to the power and tendency of Ngga'e Mbapo to community and cosmos.

\subsection{Ngga'e Mbapo - Transcendent Divinity As Well As Immanent}

The use of Mbapo at Ngga'e explains symbolism of Peo. Peo, in one side indicates Ngga'e who reigns in heaven, transendent, absolute, and dominates the universe and decides the season and the nature cycle; but on the other side, he underlies and covers everything. The branch of Peo fai is always raised above, directed to Ngga'e who resides inn unlimited height; but in the other side, his feet enshire to the ground, pierce the earth base. The plant of 
Peo pole clarifies seha tana, that the land is in the divine power (ancestor). Jawawawo people do not regard ancestor as divinity different from $N g g a$ 'e, but as reprresentative of Ngga'eMbapo in life. This plant of Peo clarifies that Ngga'e through ancestor has dominated the earth base.

This concept underlies the rit poem of kuda kepa, greeting Ngga'e with the mother of rain on water ocean (ine ko'o reta ae luma), the father of dam on the ground layer (ame ko'o ura rade tama dape). Ngga'e is the heaven master who stretches the horizon to back up the water ocean on the sky in order not to fall on earth; and to cover the water dam with land layers so as not to flood to the surface of earth. This faith of course emanates fromthe phenomena of the sky end wich is connectd with the edge of earth in the limit of eye reach. The connection of sky and earth provides the faith about celestial power which reaches up to the earth bottom. Ngga'e does not only have the power of celestial fatherhood, but also that of earth motherhood. The two divine poles derive from the same center, namely Ngga'e Mbapo.

The power of Ngga'e isnot limitd at the two poles. Ngga'e is also present in the whole area of cosmos. Prayer exclamation in pala manu rite clarifies the presence of $N g g a$ 'e on the land, east and west, the base of Peo and the yard of en'nda, the main house and the whole cosmos. The mention of places of Ngga'e's presence in not intended to localize the presence of Ngga'e Mbapo. Those locations in the paradigm of space orientation and structue of polar thinking jawawawo become coordinate spots of Ngga'e Mbapo's presence in space cosmos dealing with ancestor presence and nitu nua representing Ngga'e Mbapo's power in cosmos. Dimensionof Ngga'e preesence in space cosmos include in the second and third prayer appeal pala manu, namely Ngga'e udu rede and Mbapu eko dau. The meaning of this sentence cannot be paralleled with formulation of Ngga'e rede udu(ngga'e in the head of village) and Мвари dau eko(Мbарu in the tail of village). The turn up of sentence structurebrings abut meaning difference. Ngga'e udu rede means Ngga'e with his head above leaning on mountain, Ngga'e eko dau is Ngga'e with long tail up to the sea. This appeal wants to declare that the whole area of cosmos is covered by the presence of Ngga'e. This meaning is similar to formulation of building declaration of Peo, udu nga'o mbei kedi, a'inga'o ndeli mesi(my head leans on mountain, my feet step on sea). Ngga'e Mbapo includes and covers the whole cosmos, from mountain to sea, from east (mbisu mena) until west (menga rade). Ngga'e is Mbapo, because his divinity underlies and covers everything. Personification of Ngga'e with animal structure (head and tail) does not mean to parallel Ngga'e with animal, but use basic structure of animal to describe dimension of Ngga'e Mbapo's coverage.

\subsection{The Beckground of Tripolar Cosmology}

The divine concept of Jawawawo community has a background of tripoar cosmology(Jacobs, 2010, p. 241).Agriculturral community orientaes at the preservation of life. The principle of preservation urges the unity of opposite poles. Heaven and earth are seen as opposite poles but mutually complementary.Marriage is regarded as a model of ideal unity between opposite poles. The term ine mere and ame dewa, Ngga'e reta diru(Ngga'e inheaven) and Mbapu ndia tanah (Mbapo on land); ine ko'o ura and ame ko'o ura(mother and father of rain) clearly describes the motive of matrimonial unity between heaven pole and earth pole. The picture of world above based on man, and that of world below based on woman describs opposite poles which is mutually complementary (relative contrast). Life surely derives from earth, but this life can only continue if earth obtains seed, light and rain 
from heaven; on the contrary, heaven can pour rain if it obtains water from earth layers (tana dape). The marriage of heaven and earth for agricultural community determines the existence of life.

The marriage of two divine poles is represented with the structure of Peo aki and Peo fai. The symbolism of marriage is also shown by putting the string of prey animal at the celebration of Peo building(pala pije pu'u) in the gapof brach bottom of Peo fai ending at the bottom of Peo aki. The blood of prey animal is allowed to pour to the land as the symbol that the marrigage between the two poles produces life power for earth. This concept relates to the term fat (mina) in the declaration of Peo. Ta mina tau pisa, ndia wewa en'nda(the fat muddies the yeard, en'nda). Fat is the symbol of life abundance(la mina) and the prosperity of marriage result of the two divine poles. ${ }^{\text {ix }}$ The meeting icons of earth creature and heaven creature at Peo fai also describes marriage as well as the marriage result between cosmic world. The marriage between the divine poles becomes a guarantee of life survival for agricultural community, symbolized with two murai birds(koka) at the branch top of Peo fai. This marriage causes the koka to keep on sounding(sedho) every morning, as a symbol that life keeps on going.

Marriage akes borders of the world narrow. The creatures of the three worlds can visit each other. The middle world becomes the spot of meeting among different world creatures. The practice of offering food ( $t i$ 'i ka pembe wedu) in Jawawawo community indicates the middle world as the meeting of the three cosmic world's residents. The rites of offering food bring the humanbeing to rise up and communicate to the world above, and sometimes to the world below; on the other hand, the residents of world above come down to accept the food offer and pour their blessing.

\section{Conclusion}

There are four things which can be concluded of this analysis. First, $P e o$ in the perspective of metaphysic symbol owns revelation power. Peo reveals Ngga'e Mbapo, the highest divinity in the traditional faith of Jawawawo customary community. Peo symbolism describes th divinity of Ngga'e Mbapo, transcendent, absolute and unreachable, at once immanent, underlying and covering everything and executes history and has a role in human life.

Second, the image of revelation in Jawawawo Peo shows the model of experiencing natural monistic religiousity. Peo describes the whole cosmos covered and integrated by divine power deriving from and resting on one core, namely, Ngga'e Mbapo.

Third, authentic religiousity. The model of experiencing natural monistic religiousity shows that the religiousity of traditional Jawawawo community cannot be categorized as dynamism, animism and superstition, but an authentic religiousity because it comes from experience of genuine revelation and places the highest divinity as a basis of existence. Religiousity of traditional Jawawawo community is of course not doctrinal, but more open to mystery, and as it is a part of trying to survive the existence of community, it always relates closely to tradition, custom, and respect to the ancestors. Therefore, feasibility and legality of this religiousity cannot be measured with physical dimension, but with faith substance.

Fourth, inspiration for development of faith dialogue. The basis of assessment on faith substance requires penetrating step into the depth of religiousity, namely, what is behind the 
symbols, the rites and the life practice. In other words, assessment requires faith dialogue. This step is important for multi religious community at present to encounter the image and work of Lord in various elements of symbol, tradition, life practice and virtue of traditional faith which can enrich human existence and universal fraternity.

\section{Note}

i Wood embu, according to Verheijen belongs to kind of cassia fistula(Tule, 2004, p. 110). The plant of embu wood is due to the frequency of being used as basic material of Peo understood as ancestor representative (embu).

ii Peo gives life and revelation power to myths, Ine koto, Mbu'e Wondo, Mbu'e Dombo Nio, Wawi Tolo and Mbu'e Soa; enlightens the awareness of Jawawawo community with metaphysic dimension from life and universe.

iii Nggo damba is traditional musical instrument of Keo consisting of a series of gong and a drum usually usedto accompany traditional dance (bebi ja'i)

iv Bebi ja' $i$ is term usually used for tranditional dance of Keo

$\checkmark \quad$ Narois rite dance in the tradition of $P e o$ restoration by surrounding campfire as a center while stepping the feet in line withcertain rhyme, and singing poems about community geanology and origin of cosmos. The core of naro lies at reko(episode) containing dhuju nama(tale of ancestor genealogy), virtue, and role to the building and development of custom community. Naro fro Jawawawo is sacred tale so it must be done with respect and solemnity.

vi Similarthought is found in almost all tribes of NTT(Fernandez, 1991).Sumba community always positions the dead body by sitting and bending like the position of baby inthe womb. The ame faith also occurs in many archipelago tribes. Toraja Mamasa, South Sulawesi people describe that woman derives from earth, facing the man descending from heaven(Kess, 2006). Mircea Eliade in his research to archaic community also found the same phenomena in many tribes in the world. Mediterranean religion calls earth mother (terrae mater) as giving birth to all forms of life(Eliade, 1987, pp. 138-139).

vii The myth of wawi tolo(red pig) telling abut the appearance of human female from red pig in a spring seems to describe the origin of human beings in the earth. The same pattern is also found in myth of Mbue soa(Soa girl) and Mbu'e Dumbo Nio (coconut top girl). The legend ine koto which gives birth to descendants of result of sexual intercourse with stone surely has a background of identification of mother with land.

viii Another concept that must be taken care of in interpreting the term Keo is word partner which does not have a direct meaning. E.g the word embu mame, literally means grandfa/grandma and ucle, but the real meaning is the side who gives mother (mother giver). The term tu'a eja, literally means parents in-law or brother in-law, but the real meaning is the customary rite of marriage ceremony. Pi' $i$ singi, rete ra' $i$ literally means to urinate, to press while the real meaning is movement or annexation of land border.

ix The term mina in Keo community is often united with la, so that it becomes la mina.The term la mina has a meaning of family relation or kinship relation. 


\section{References}

Amstrong, K. (2002). Sejarah Tuhan. Bandung: Mizan. References

Eliade, M. (1987). The Sacred and the Propane: The Nature of Religion. Orlando-Florida: Harvest Book- Harcourt.

Fernandez, S.A. (1991). Kebijaksanaan Manusia Nusa tenggara Timur Dulu dan Kini. Ledalero: STFT St. Paulus.

Forth, G. (2002). Dualisme and Hierarchy: Processes of Binary Combination in Keo Society. New York: Axford Studies in Social and Cultural Antropology.

Fransiskus. (2016). Peran Peo pada Masyarakata adat Bhela dan Korelasinya dengan Salib Kristus: Sebuah Refleksi Antropologis Teologis. Ledalero: STFT Ledalero.

Gani, L. (2017). Myths of Central Keo Community [Interview] (24 February 2017).

Gani, L. (2017). Ngga'e is ta mudu, ta mudu odo, Mbapo ta ebho, ta ebho geo [Interview] (7 and 23 June 2018).

Gani, L. (2017). Symbolisme of Peo [Interview] (22 February 2018).

Heuken, A. (1991). Ensklopedi Gereja, Jilid I. 1 ed. Jakarta: Yayasan Cipta Loka Caraka.

Kniter, P. F., (2008). Pengantar Teologi Agama-Agama. Yogyakarta: Kanisius.KWI, Dokpen. 1993.

KWI, D. Dokumen Konsili Vatikan II. Jakarta: Obor.

Jacobs, S. (2010). Estetika Paradoks. Bandung: Sunan Umbu Press.

Jaspers, K.(1959). Truth and Symbol, taken from Von de Wahrheit. New York: Tweyne.

Jaspers, K. (1971). Philosphy, Volume 3. Chicago and London: The University of Chicago.

Ngada K, Badan Pusat Statistik. (2009). Nagekeo dalam Angka, Bajawa: Badan Pusat Statistik Kabupaten Ngada.

Rangga, S. (2017). Symbolism of Peo [Interview] (28 February 2017).

Ryanto, A. (2014). Dialog Intereligius. Yoryakarta: Kanisius.

Tule, Philipus. (1998). Keonese - Indonesia - English Dictionary: With Provers, Myths, Chant and Prayers. Canberra: Deparment of Antropology Reseach School of Pacific and Asian Studies Australian National University.

Tule, Philipus. (2004). Longing for the House of God, Dwelling in the House of Ancestors. Saint Agustin-Germany: Studia Institut Anthropos, Academic Press Fribourg Switzerland.

Tule, Philipus. (2017). Symbolism of Peo [Interview] (22 February 2017).

Zoetmulder, P.J. (1990). Manunggaling Kawula Gusti. Patheisme dan Monisme dalam Sastra Suluk Jawa. Jakarta: Gramedia. 